\title{
Orphandev, French Clinical Trials Network dedicated to Orphan drugs and therapeutics development for rare diseases
}

\author{
Yolande Adjibi*, Joëlle Micallef, Olivier Blin \\ From 5th European Conference on Rare Diseases (ECRD 2010) \\ Krakow, Poland. 13-15 May 2010
}

Though rare diseases affect fewer patients than common diseases, developing drugs for them is subject to the same principles. But constructing and leading rare diseases clinical trials means also facing numerous difficulties which are more important in this field (methodology, little knowledge of the disease's evolution, choice of the judgment's criteria, small population's size, logistical matters...)

However during the last decade, France led several initiatives to improve the burden of rare diseases. Centres of Expertise were identified, ability centres have been appointed and a National Plan for rare diseases was developed.

Nevertheless, in spite of the great dynamic created by France, development and availability of orphan therapeutics remain problematic regarding rare diseases specificities. In this context, it is important to gather skills and strengths to make patients benefit from fundamental research's results and accelerate clinical trials.

Orphandev is a French Clinical Trials Network based on a strong collaboration principle with all actors involved (academics, industries and patients) dedicated to orphan drugs development. It was created by academics to help academics but also others actors involved in rare diseases' research. The Network' skills have already been dedicated to orphan drugs' trials: Charcot Marie Tooth (2004), Rett (2006) and Progeria (2008). Orphandev has intervened according to the mutualisation and translational research concepts from the experimental phase (in vitro and animals' tests) to the results' valorisation with every single actor involved in

*Correspondence: yolande.Adjibi@ap-hm.fr

CIC CPCET Timone Hospital, Hôpital de la Timone bât F 264 rue Saint Pierre, 3385 Marseille, France the study. With the experience gained and the successful results, we have developed an organisational concept in order to capitalise on the lessons learnt and optimise the trials process.

In a time of great therapeutics development with solutions coming from gene breakthroughs but not only, Orphandev allows for further improvement of the interface between fundamental research, clinical research and drug developments in rare diseases in a more operational way.

Published: 19 October 2010

doi:10.1186/1750-1172-5-S1-P11

Cite this article as: Adjibi et al:: Orphandev, French Clinical Trials

Network dedicated to Orphan drugs and therapeutics development for rare diseases. Orphanet Journal of Rare Diseases 2010 5(Suppl 1):P11.

Submit your next manuscript to BioMed Central and take full advantage of:

- Convenient online submission

- Thorough peer review

- No space constraints or color figure charges

- Immediate publication on acceptance

- Inclusion in PubMed, CAS, Scopus and Google Scholar

- Research which is freely available for redistribution

Submit your manuscript at www biomedcentral.com/submit
Biomed Central 